UDC 577.21

\title{
CRISPR/Cas9 technology for targeted genome editing
}

\author{
N. A. Lomov ${ }^{1,3}$, V. V. Borunova ${ }^{1,3}$, M. A. Rubtsov'1,2,3 \\ ${ }^{1} \mathrm{M}$. V. Lomonosov Moscow State University, \\ Leninskie Gory, 1/12, Moscow, Russian Federation, 119991 \\ 2 I. M. Sechenov First Moscow State Medical University, \\ 8, Trubetskaya Str. Moscow, Russian Federation, 119991 \\ ${ }^{3}$ LIA 1066 French-Russian Joint Cancer Research Laboratory \\ Villejuif, France-Moscow, Russian Federation \\ ma_rubtsov@mail.ru
}

CRISPRs (Clustered Regularly Interspaced Short Palindromic Repeats) are the segments of prokaryotic DNA containing short repeats in its nucleotide sequence. Today we know that this is a bacterial protection system against viral DNA. The molecular components of CRISPR/Cas9 system have been used for a gene editing in eukaryotes since 2013. But as any other method it also has the limitations and drawbacks. Here we are going to review the history of CRISPR biology and to discuss the possibilities that this new technology provides to researchers as well as the prospects for its use in the medical research and treatment.

Keyw ords: CRISPR/Cas9, genome targeting, genome editing, personalized therapy, chromosomal translocations, DNA repair.

\section{History}

The specific sequences in bacterial genomes, called CRISPR, were discovered in 1987. They consist of repeats, alternating by unique sequences or «spacers» [1] (Fig. 1, A). Its function has been unsolved until 2005 when it was found that these «spacers» have a sequence equal to a viral DNA. It was also observed that there are the CRISPR-associated genes and these genes encode nucleases. Afterwards it was supposed that the bacteria use these nucleases to cleave a foreign DNA wherein the spacer sequence is used as an example of which exactly DNA sequence is necessary to be cut $[2,3]$. This hypothesis was experimentally proven in 2007 [4]. A detailed mechanism of the complex maturation and directed cleavage of DNA was finally studied in 2011 [5] (Fig. 1, B). It was found that the
Cas9 enzyme formed a ternary complex with crRNA and tracrRNA encoded in the cluster. This complex unwinds DNA and introduce a double-stranded break in DNA if crRNA binds complementary to one of the DNA chains (Fig. 2, A). A year later it was shown that crRNA can be joint to tracrRNA and that this «single guide» RNA (sgRNA) together with the Cas9 enzyme might be used to modify the genome of eukaryotes [6] (Fig. 2, B). This idea was realized in 2013 and since then thousands of papers where such technology was applied have been published [7-9].

The approaches to targeted DNA breakage based on the usage of zinc finger nucleases (ZFNs) and TAL effector nucleases (TALENs) were developed much earlier in 2003 and 2009 respectively. Both methods are based on the DNA recognition by the specific proteins designed individually for each par-

(C) 2015 N. A. Lomov et al.; Published by the Institute of Molecular Biology and Genetics, NAS of Ukraine on behalf of Biopolymers and Cell. This is an Open Access article distributed under the terms of the Creative Commons Attribution License (http://creativecommons.org/licenses/by/4.0/), which permits unrestricted reuse, distribution, and reproduction in any medium, provided the original work is properly cited 
ticular sequence $[10,11]$. Compared to the these technologies the CRISPR/Cas9 system has proved to be much more simple, available, affordable and three to four times more efficient [12].

\section{The basic principle of CRISPR/Cas9 technology}

At the heart of all the methods that use the CRISPR/ Cas9 system lies the possibility to introduce a break in DNA in an exactly desired locus. It's enough to deliver the Cas9 gene (or its mRNA) together with sgRNA into the cell, wherein sgRNA at its 5'-end should have 20 nucleotide sequence complimentary
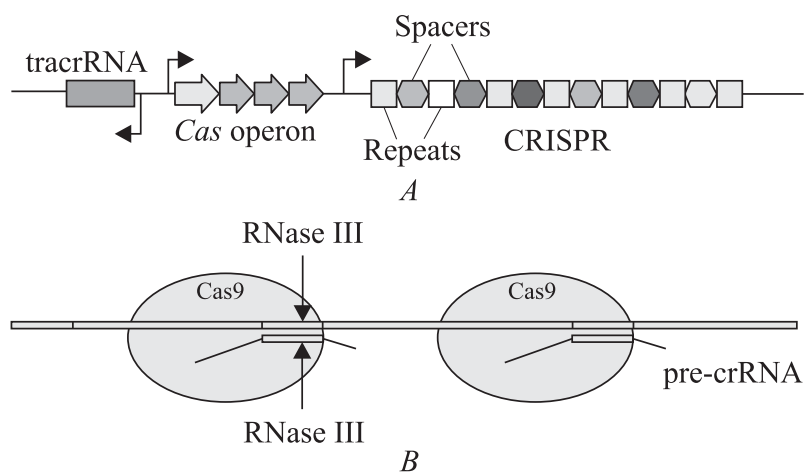

Fig. 1. A - The overall structure of the CRISPR loci. B - Mechanism of CRISPR/Cas9 complex maturation
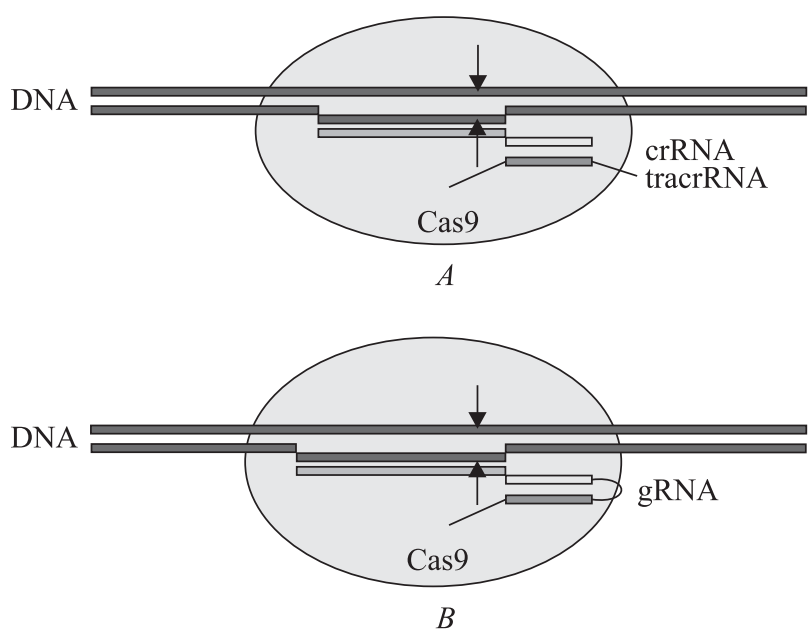

Fig. 2. $A$ - Targeted cleavage of DNA by a ternary complex of Cas 9 with crRNA and tracrRNA. $B$ - Targeted cleavage of DNA by a complex of Cas9 with «single guide» RNA (sgRNA) to a target DNA fragment. There is also easy way to introduce the multiple breaks at the same time - just to use several different sgRNAs [13].

\section{Application of CRISPR/Cas9 technology}

The first example of application of the CRISPR/ Cas 9 technology is the modeling of tumor-associated chromosomal translocations: CRISPR/Cas9 induces the double-stranded DNA breaks (DSBs) in the precise loci which are known to participate in the oncogenic rearrangements. Typically, DSBs used to be repaired by the mechanism of non-homologous end joining (NHEJ). This error prone mechanism frequently leads to joining the DNA ends belonging to different chromosomes [14]. The cellular models of certain types of cancer might be obtained using this method. Inducing the human specific types of cancer in laboratory animals is also possible. So, the murine model of non-small-cell lung cancer (NSCLC) was developed. Using lentiviral delivery the Cas9 gene and sgRNA were brought into lung cells in order to induce a cleavage of the murine endogenous Eml4 and Alk loci and to generate the Eml4-Alk fused gene found recurrently in NSCLCs. The result was the development of the disease in the treated mice [15]. To date the murine in vivo models of human leukemia (namely, AML) have also been developed $[16,17]$. These and other similar murine models can be utilized to study the carcinogenesis and to test new treatment approaches.

The next purpose which might be successfully achieved by application of the CRISPR/Cas9 technology is knocking genes out. The DSB formation often leads to the deletion or insertion of several nucleotides in an initial sequence even in case of efficient DSB repair [18]. Thus, introducing a break into a particular gene one may cause its knockout. So the Cas9-expressing cell line treated with various sgRNA can be used for searching for the genes responsible for a specific disease. A few years earlier each gene knockout was a complicated time-consuming procedure, but in case of CRISPR/Cas9 it requires only to treat the Cas9-expressing cells with a specific sgRNA [19].

In addition, one may insert the desired DNA fragment into the specific broken DNA site. There are 
two major mechanisms of DSB repair: homologydirected repair (HDR) and non-homologous end joining (NHEJ). HDR requires a fragment of DNA homologous to the damaged one as a template. Otherwise, in the absence of such a fragment, NHEJ takes place. It is possible to achieve insertion of a desired DNA fragment in both cases. If a DNA fragment with homology arms surrounding a desired gene is available, it will be inserted via HDR. In case of the NHEJ repair it is sufficient to deliver a linear DNA fragment with the ends protected from the action of cellular exonucleases. There is a chance that this fragment will be joined to the ends of the break.

So, the CRISPR/Cas9 technology makes possible the insertion of the desired DNA fragment into the genome. It is widely used in scientific research and offers great opportunities for the treatment of hereditary diseases and viral infections. For example, this technology allows generation of the stable cell lines with the desired inserts in the genome. The CRISPR/Cas9 gene knocking occurs with a much higher efficiency than the random integration of a plasmid into the genome and solely at the particular pre-selected site in almost $100 \%$ of cases. Until recently the generation of a stable cell line usually took at least few months, with the CRISPR/ Cas9 technology - up to one month [20].

Moreover, until recently, the gene therapy implied the insertion of the desired gene into the random place in the genome. In its turn, the CRISPR/Cas9 system allows changes in a certain place, where one may not only insert the gene but also remove or replace the certain DNA fragments. Several in vivo studies in mice have shown the possibility of gene therapy by means of the CRISPR/Cas9 application. A deletion of $1 \mathrm{bp}$ in the CRYGC gene is known to cause the cataract in mice. After injection of the Cas 9 mRNA, sgRNA and the DNA fragment containing a wild-type allele into the mouse embryos with this mutation the mousekins were born healthy [21]. In a recent work the researchers have successfully applied the CRISPR/ Cas9 system in order to reduce the level of cholesterol in the blood of mice by turning off the PCSK9 gene in the liver cells. They used adenovirus particles to deliver the Cas9 gene and sgRNA into hepatocytes. As a result more than $50 \%$ of hepatocytes were «edited» and it resulted in a decrease in the cholesterol level to a value that is typical for the PCSK9 knockout mice [22]. Striking results were achieved with CRISPR/ Cas9 in the prevention of Duchene's muscular dystrophy (DMD) in mice by correcting the $d m d$ dystrophin gene. A copy of the normal dmd gene was integrated in the zygotes via the CRISPR/Cas9 system. The born animals were mosaic in the $d m d$ gene but nonetheless even a partial gene editing has prevented the disease development [23].

The ability to deliver the CRISPR/Cas9 system elements into the brain cells has been also recently demonstrated. Because of the packaging size limitation of the adeno-associated viral (AAV) vectors, the dual-vector system was designed composed of two separate vectors that package the SpCas9 (AAV-SpCas9) and sgRNA (AAV-SpGuide) expression cassettes. However, the co-transfection efficiency was shown to be rather high [19].

Taken together, these in vivo studies on animals prove the excellent prospects for the genome editing via application of the CRISPR/Cas9 technology.

On the other hand, many studies ex vivo show the ability to edit DNA in human cells. The particular mutations in the CCR5 gene which occur in some people are known to make it resistant to HIV. A recent study has established that the CRISPR/Cas9based editing of CCR5 in the induced pluripotent stem cells (iPSCs) may lead to the HIV-1 resistance of descendant lymphocytes [12].

The possibility to treat the latent virus infection has also been recently demonstrated: the patient-derived cells from a Burkitt's lymphoma with latent Epstein-Barr virus infection showed a proliferation arrest and a concomitant decrease in viral load after targeting the viral genome by the CRISPR/Cas9 system elements [24]. Finally, the healthy gene copy was introduced in cells of the patients with cystic fibrosis via CRISPR/Cas9. As a result the cells demonstrated a healthy phenotype [25].

Taken together with the fact demonstrating that the «in vitro corrected» organs might be successfully transplanted back into the body in mice [26], the above experiments give us a hope for the successful application of this experience in the treatment of pa- 
tients. This considerably strengthens the position of gene therapy among the advanced treatments of the genetic and viral diseases in humans.

An especial theme is the editing of the human embryo genome. Such possibility opens up broad prospects for the prenatal correction of the «broken» genes. The researchers from Sun Yat-sen University, China, have already tested this potential. They used triplonuclear zygotes (for ethical reasons) and replaced the $H B B$ gene using the CRISPR/Cas9 technique. As a result it was shown that: 1) the effectiveness of the replacement of a normal gene copy by means of HDR in these cells was relatively low; 2) the edited embryos were mosaic; 3 ) the mutations in the genome located in not-planned loci was identified (socalled «off-target» mutations); 4) another highly homologous gene (HBD) could serve as a donor template for HDR. However, despite the difficulties this study shows the fundamental possibility of the genome editing in human embryos [27].

\section{Drawbacks of CRISPR/Cas9 technology}

The common problem of all genome editing methods is so called «off-target» effects - when a nuclease cleaves DNA not in the place where it was intended. It may impair the function of any incidental gene or may lead to integration of the desired gene in the wrong place and genome surrounding. In case of human embryos such a risk is absolutely unacceptable. In the abovementioned work with the human embryos several off-target mutations have been found and documented, but later the authors noticed that three out of four of them were polymorphisms already presented in the germline and were not associated with the CRISPR/Cas9 action. The special studies show that the level of off-target mutations in case of the CRISPR/Cas9 application is in fact extremely low [28]. Today, several methods for measuring the off-target editing have been developed. The first method is based on the fluorescent in situ hybridization (FISH): one fluorescent probe anneals to the insertion fragment and another fluorescent probe detects the insertion site. Normally these two probes have to be colocalized otherwise it is the erroneous insertion [29]. Other method (GUIDE-seq) is based on the addition of short DNA fragments which would be integrated at the breaks. These fragments of DNA are then used as anchors when surrounding DNA is amplified by PCR and sequenced. So one we can see all sites of insertion of these fragments and count off-target mutations [30]. These evaluation methods have shown that not all of the off-target sites might be predicted by special computer software and that the different sgRNA provides a different number of these effects.

The various methods to improve the accuracy and efficiency of insertion were proposed. For example, in order to obtain a higher specificity a «double nicking» method might be used [31]. It consists in special modification of Cas9 resulting in an ability of the enzyme to introduce break in only one DNA strand («nick»). Thus, for the formation of a doublestranded break two such nickases should work vis-avis. Furthermore, each of the enzymes has to bind its own sgRNA which should recognize its own (mutually complementary) DNA sequence. Thus, the probability of double-stranded breakage in the off-target sites reduces dramatically.

In order to increase the efficiency of the insertion in the genome the HDR mechanism should prevail. To achieve this goal the NHEJ-inhibiting agents might be used. In particular DNA ligase IV which plays an important role in NHEJ might be turned off by using the Scr7 agent. This may increase the efficacy of DNA integration up to 19 times [32].

The selection of sgRNA sequences should be performed in such a way to reduce the probability of the off-target effects. The special algorithms have been developed for this purpose (CRISPR Design Tool: http://tools.genome-engineering.org). If there is need for especial accuracy it is necessary to check a number of the off-target sites by applying the GUIDEseq technique.

Finally, the integration of new genes requires a special attention when selecting the integration site. Such target should be a locus where the inserted DNA fragment would be «protected» against the epigenetic effects, would work in a predictable manner and would not cause negative effects on a cell, for example, induce carcinogenesis. Such loci are called 
«genomic safe harbors» (GSHs). They should be located far from other genes especially protooncogenes and at the same time should be outside the transcription units and the ultra-conserved DNA regions. The sites suitable as GSHs might be identified by the bioinformatics methods but also require experimental confirmation [33].

\section{Conclusion}

So far we can say with confidence that the CRISPR/ Cas9-based technologies have revolutionized the biomedical science and are spreading at a remarkable speed by virtue of their simplicity and efficiency. The CRISPR/Cas9 application dramatically facilitates the manipulation with DNA in terms of providing the targeted genome editing, foremost deletions or gene replacement. Despite some drawbacks this technology has a wide perspective in the fields of basic research, biotechnology, translational and personalized medicine.

\section{Acknowledgments}

N. A. L., V. V. B., and M. A. R.: RFBR (grants 14-0493105-CNRS_a, 15-54-16007-CNRS_a).

\section{Competing interests}

The authors declare no competing interests.

\section{REFERENCES}

1. Ishino $Y$, Shinagawa H, Makino K, Amemura M, Nakata A. Nucleotide sequence of the iap gene, responsible for alkaline phosphatase isozyme conversion in Escherichia coli, and identification of the gene product. J Bacteriol. 1987;169 (12):5429-33.

2. Bolotin A, Quinquis B, Sorokin A, Ehrlich SD. Clustered regularly interspaced short palindrome repeats (CRISPRs) have spacers of extrachromosomal origin. Microbiology. 2005; 151(Pt 8):2551-61.

3. Makarova KS, Grishin NV, Shabalina SA, Wolf YI, Koonin EV. A putative RNA-interference-based immune system in prokaryotes: computational analysis of the predicted enzymatic machinery, functional analogies with eukaryotic RNAi, and hypothetical mechanisms of action. Biol Direct. 2006;1:7.

4. Barrangou R, Fremaux C, Deveau H, Richards $M$, Boyaval $P$, Moineau S, Romero DA, Horvath P. CRISPR provides acquired resistance against viruses in prokaryotes. Science. 2007; 315(5819):1709-12.
5. Deltcheva E, Chylinski K, Sharma CM, Gonzales K, Chao Y, Pirzada ZA, Eckert MR, Vogel J, Charpentier E. CRISPR RNA maturation by trans-encoded small RNA and host factor RNase III. Nature. 2011;471(7340):602-7.

6. Jinek M, Chylinski K, Fonfara I, Hauer M, Doudna JA, Charpentier E. A programmable dual-RNA-guided DNA endonuclease in adaptive bacterial immunity. Science. 2012;337 (6096):816-21.

7. Cong L, Ran FA, Cox D, Lin S, Barretto R, Habib N, Hsu PD, Wu X, Jiang W, Marraffini LA, Zhang F. Multiplex genome engineering using CRISPR/Cas systems. Science. 2013; 339 (6121):819-23.

8. Mali P, Yang L, Esvelt KM, Aach J, Guell M, DiCarlo JE, Norville JE, Church GM. RNA-guided human genome engineering via Cas9. Science. 2013;339(6121):823-6.

9. Jinek M, East A, Cheng A, Lin S, Ma E, Doudna J. RNAprogrammed genome editing in human cells. Elife. 2013; 2: e00471.

10. Bibikova M, Beumer K, Trautman JK, Carroll D. Enhancing gene targeting with designed zinc finger nucleases. Science. 2003;300(5620):764.

11. Christian M, Cermak T, Doyle EL, Schmidt C, Zhang F, Hummel A, Bogdanove AJ, Voytas DF. Targeting DNA doublestrand breaks with TAL effector nucleases. Genetics. 2010; 186(2):757-61.

12. Ye L, Wang J, Beyer AI, Teque F, Cradick TJ, Qi Z, Chang JC, Bao G, Muench MO, Yu J, Levy JA, Kan YW. Seamless modification of wild-type induced pluripotent stem cells to the natural CCR5 32 mutation confers resistance to HIV infection. Proc Natl Acad Sci U S A. 2014;111(26):9591-6.

13. Kabadi AM, Ousterout DG, Hilton IB, Gersbach CA. Multiplex CRISPR/Cas9-based genome engineering from a single lentiviral vector. Nucleic Acids Res. 2014;42(19):e147.

14. Lieber MR, Gu J, Lu H, Shimazaki N, Tsai AG. Nonhomologous DNA end joining (NHEJ) and chromosomal translocations in humans. Subcell Biochem. 2010;50:279-96.

15. Blasco RB, Karaca E, Ambrogio C, Cheong TC, Karayol E, Minero VG, Voena $C$, Chiarle $R$. Simple and rapid in vivo generation of chromosomal rearrangements using CRISPR/ Cas9 technology. Cell Rep. 2014;9(4):1219-27.

16. Heckl D, Kowalczyk MS, Yudovich D, Belizaire R, Puram $R V$, McConkey ME, Thielke A, Aster JC, Regev A, Ebert BL. Generation of mouse models of myeloid malignancy with combinatorial genetic lesions using CRISPR-Cas9 genome editing. Nat Biotechnol. 2014;32(9):941-6.

17. Chen C, Liu Y, Rappaport AR, Kitzing T, Schultz N, Zhao Z, Shroff AS, Dickins RA, Vakoc CR, Bradner JE, Stock W, LeBeau MM, Shannon KM, Kogan S, Zuber J, Lowe SW. MLL3 is a haploinsufficient $7 \mathrm{q}$ tumor suppressor in acute myeloid leukemia. Cancer Cell. 2014;25(5):652-65.

18. Ran FA, Hsu PD, Wright J, Agarwala V, Scott DA, Zhang F. Genome engineering using the CRISPR-Cas9 system. Nat Protoc. 2013;8(11):2281-308. 
19. Swiech L, Heidenreich M, Banerjee A, Habib N, Li Y, Trombetta J, Sur M, Zhang F. In vivo interrogation of gene function in the mammalian brain using CRISPR-Cas9. Nat Biotechnol. 2015;33(1):102-6.

20. Merkle FT, Neuhausser WM, Santos D, Valen E, Gagnon JA, Maas K, Sandoe J, Schier AF, Eggan K. Efficient CRISPRCas9-mediated generation of knockin human pluripotent stem cells lacking undesired mutations at the targeted locus. Cell Rep. 2015;11(6):875-83.

21. Wu Y, Liang D, Wang Y, Bai M, Tang W, Bao S, Yan Z, Li D, $\mathrm{Li} \mathrm{J}$. Correction of a genetic disease in mouse via use of CRISPR-Cas9. Cell Stem Cell. 2013;13(6):659-62.

22. Ding Q, Strong A, Patel KM, Ng SL, Gosis BS, Regan SN, Cowan CA, Rader DJ, Musunuru K. Permanent alteration of PCSK9 with in vivo CRISPR-Cas9 genome editing. Circ Res. 2014;115(5):488-92.

23. Long C, McAnally JR, Shelton JM, Mireault AA, BasselDuby $R$, Olson EN. Prevention of muscular dystrophy in mice by CRISPR/Cas9-mediated editing of germline DNA. Science. 2014;345(6201):1184-8.

24. Wang J, Quake SR. RNA-guided endonuclease provides a therapeutic strategy to cure latent herpesviridae infection. Proc Natl Acad Sci U S A. 2014;111(36):13157-62.

25. Schwank G, Koo BK, Sasselli V, Dekkers JF, Heo I, Demircan T, Sasaki N, Boymans S, Cuppen E, van der Ent CK, Nieuwenhuis EE, Beekman JM, Clevers H. Functional repair of CFTR by CRISPR/Cas9 in intestinal stem cell organoids of cystic fibrosis patients. Cell Stem Cell. 2013;13(6): 653-8.

26. Yui S, Nakamura T, Sato T, Nemoto Y, Mizutani T, Zheng $X$, Ichinose S, Nagaishi T, Okamoto R, Tsuchiya K, Clevers $H$, Watanabe $M$. Functional engraftment of colon epithelium expanded in vitro from a single adult Lgr5+ stem cell. Nat Med. 2012;18(4):618-23.

27. Liang $P, X u Y$, Zhang $X$, Ding C, Huang $R$, Zhang Z, Lv J, Xie X, Chen Y, Li Y, Sun Y, Bai Y, Songyang Z, Ma W, Zhou $C$, Huang J. CRISPR/Cas9-mediated gene editing in human tripronuclear zygotes. Protein Cell. 2015;6(5):363-72.

28. Iyer $V$, Shen B, Zhang $W$, Hodgkins A, Keane T, Huang $X$, Skarnes WC. Off-target mutations are rare in Cas9-modified mice. Nat Methods. 2015;12(6):479.

29. Paulis M, Castelli A, Lizier M, Susani L, Lucchini F, Villa A, Vezzoni $P$. A pre-screening FISH-based method to detect CRISPR/Cas9 off-targets in mouse embryonic stem cells. Sci Rep. 2015;5:12327.

30. Tsai SQ, Zheng Z, Nguyen NT, Liebers M, Topkar VV, Thapar $V$, Wyvekens $N$, Khayter C, Iafrate AJ, Le LP, Aryee MJ, Joung JK. GUIDE-seq enables genome-wide profiling of off-target cleavage by CRISPR-Cas nucleases. Nat Biotechnol. 2015;33(2):187-97.
31. Ran FA, Hsu PD, Lin CY, Gootenberg JS, Konermann S, Trevino AE, Scott DA, Inoue A, Matoba S, Zhang Y, Zhang F. Double nicking by RNA-guided CRISPR Cas9 for enhanced genome editing specificity. Cell. 2013;154(6): 1380-9.

32. Maruyama T, Dougan SK, Truttmann MC, Bilate AM, Ingram JR, Ploegh HL. Increasing the efficiency of precise genome editing with CRISPR-Cas9 by inhibition of nonhomologous end joining. Nat Biotechnol. 2015;33(5):538-42.

\section{CRISPR/Cas9 технологія}

для цільового редагування геному

\section{Н. А. Ломов, В. В. Борунова, М. А. Рубцов}

CRISPRs (Clustered Regularly Interspaced Short Palindromic Repeats) - послідовності в геномі прокариот, які складаються 3 коротких повторів, що перемежовуються унікальними послідовностями. Це система бактеріальної захисту від вірусної ДНК. Молекулярні компоненти даної системи з 2013 року використовуються як інструмент редагування еукаріотічесого геному, хоча дана технологія і має деякі обмеження і недоліки. У даному огляді ми торкнемося історію застосування системи CRISPR / Cas9 і обговоримо можливості, які дана технологія надає для дослідження і лікування різних захворювань.

Ключевы е слов а: CRISPR/Cas9, тагретінг генома, редагування геному, персоналізована терапія, хромосомні транслокації, репарація ДНК.

\section{CRISPR/Cas9 технология}

для целевого редактирования генома

\section{Н. А. Ломов, В. В. Борунова, М. А. Рубцов}

CRISPRs (Clustered Regularly Interspaced Short Palindromic Repeats) - последовательности в геноме прокариот, которые состоят из коротких повторов, перемежающихся уникальными последовательностями. Это система бактериальной защиты от вирусной ДНК. Молекулярные компоненты данной системы с 2013 года используются как инструмент редактирования эукариотического генома, хотя данная технология и имеет некоторые ограничения и недостатки. В данном обзоре мы затронем историю применения системы CRISPR/Cas9 и обсудим возможности, которые данная технология предоставляет для исследования и лечения различных заболеваний.

Ключевы е слова: CRISPR/Cas9, таргетинг генома, редактирование генома, персонализированая терапия, хромосоные транслокации, репарация ДНК.

Received 01.07.2015 